\title{
Content Validity of the Enjoyment Instrument in Physical Education Learning:
}

\author{
A Field Study \\ Sucipto Sucipto*, Beltasar Tarigan, Amung Ma’mun, Yunyun Yudiana \\ Sports Education Graduate School \\ Universitas Pendidikan Indonesia \\ Bandung, Indonesia \\ *sucipto@upi.edu, yunyunyudiana@upi.edu
}

\begin{abstract}
This study aims to estimate the value of the validity of the content of the instrument of exercise enjoyment in physical education. The study was conducted on seven lecturers as academics called the Subject Metter Expert (SME). This preliminary research was carried out in the city of Bandung Indonesia by conducting Focus Group Discourse (FGD) to assess the suitability of the items developed in measuring the pleasure of exercising during the lesson. The instrument was developed to adapt from Kendzierski and DeCarlo called Physical Activity Enjoyment Scale (PACES) which consists of 18 items. The analysis technique uses content validity ratio (CVR) analysis from lawshe. The results of data analysis using estimated content validity (Lawshe's CVR), obtained the value of the ratio between 0.71 to 1.00. This value exceeds the minimum limit value of 0.50 as an acceptable ratio value limit. Thus, the results of this initial stage of validation show that the instrument of pleasure in sports on teaching learning is proven to be valid in content in measuring the level of enjoyment of students.
\end{abstract} $(\mathrm{CVR})$

Keywords - content validity; enjoyment; Content Validity Ratio

\section{INTRODUCTION}

In teaching and learning processes, learning outcome measurement is an important aspect, either in elementary or secondary school aiming at assessing students' ability after learning $[1,2]$. Thus, in measurement, there are instruments used to measure such aspects as cognition, affection, and psychomotor. Good instruments have two main criteria including validity and reliability [3]. In Indonesia, the latest curriculum namely Curriculum 2013 demands all the learning processes to involve cognitive, affective, and psychomotoric domains. Thus, physical education needs to be an integral part of physical activity [4]. To this relation, enjoyment plays an important part of physical education [5]. It is believed that students will be motivated to have more physical activity if they have enjoyment in doing so.

One of the instruments used to measure students' enjoyment in physical education is namely Physical Activity Enjoyment Scale (PACES) developed by Kendzierski and DeCarlo, however, the validity and reliability of the instrument have not been proven so that further investigation on it needs to be performed. One of the important aspects to identify in the measurement is the so-called content validity which is closely related to expert judgment of the instrument, particularly regarding the measurement of the affective aspects. It has been shown that content validity is rarely used in the contexts of sport and physical education.

Based on the aforementioned reasons, this study aimed to conduct a validity test of the enjoyment instrument prior to its use, particularly regarding the content validity of the instrument.

\section{METHOD}

\section{A. Participants}

There were seven people from academics and practitioners serving as respondents in this study. To measure the item suitability developed, the experts were called subject matter expert (SME) where they were selected purposively [6]. The respondents were lecturers with expertise in sport pedagogy, sport psychology, and physical education teachers as practitioners.

\section{B. Procedure}

The study was took place at the Faculty of Sport and Health Education, Universitas Pendidikan Indonesia, Indonesia, through a Focus Group Discussion (FGD) [7]. This aimed to discuss the check the item suitability developed [8].

\section{Instrument}

The instrument in this study was PACES developed by Kendzierski and DeCarlo conssiting of 13 questions on students' enjoyment in doing football in physical education [9].

\section{Data Analysis Technique}

The statistical data analysis technique used in this study was Content Validity Ratio Lawshe [7,8,10,11] aiming at estimating the content validity based on the judgment of seven SMEs. The formula is as follows. 


$$
C V R=\frac{M_{p}-\frac{M}{2}}{\frac{M}{2}}=\frac{2 M_{p}}{M}-1
$$

where:

$\mathrm{Mp}=$ the number of experts stating that it is important;

$\mathrm{M}=$ the number of experts validating

With the ratio index $-1 \leq \mathrm{CVR} \leq+1$ and the following criteria:

$$
\begin{array}{ll}
\mathrm{Mp}<1 / 2 \mathrm{M} & \text { Then } \mathrm{CVR}<0 \\
\mathrm{Mp}=1 / 2 \mathrm{M} & \text { Then } \mathrm{CVR}=0 \\
\mathrm{Mp}>1 / 2 \mathrm{M} & \text { Then } \mathrm{CVR}>0
\end{array}
$$

\begin{tabular}{|c|c|c|c|c|c|c|c|c|c|c|c|}
\hline \multirow{2}{*}{$\begin{array}{l}\text { Variable/ } \\
\text { Indicator }\end{array}$} & \multirow{2}{*}{ Item } & \multicolumn{7}{|c|}{ Expert Judgment } & \multirow{2}{*}{ JK } & \multirow{2}{*}{$\mathbf{M}$} & \multirow{2}{*}{ CVR } \\
\hline & & 1 & 2 & 3 & 4 & 5 & 6 & 7 & & & \\
\hline \multirow{13}{*}{ Enjoyment } & $\begin{array}{c}\text { Item } \\
1\end{array}$ & 1 & 1 & 1 & 1 & 1 & 0 & 1 & 6 & 0.86 & 0.71 \\
\hline & $\begin{array}{c}\text { Item } \\
2\end{array}$ & 0 & 1 & 1 & 1 & 1 & 1 & 1 & 6 & 0.86 & 0.71 \\
\hline & $\begin{array}{c}\text { Item } \\
3\end{array}$ & 1 & 1 & 1 & 1 & 1 & 1 & 1 & 7 & 1.00 & 1.00 \\
\hline & $\begin{array}{c}\text { Item } \\
4\end{array}$ & 1 & 0 & 1 & 1 & 1 & 1 & 1 & 6 & 0.86 & 0.71 \\
\hline & $\begin{array}{c}\text { Item } \\
5\end{array}$ & 1 & 1 & 1 & 1 & 1 & 0 & 1 & 6 & 0.86 & 0.71 \\
\hline & $\begin{array}{c}\text { Item } \\
6\end{array}$ & 1 & 1 & 1 & 0 & 1 & 1 & 1 & 6 & 0.86 & 0.71 \\
\hline & $\begin{array}{c}\text { Item } \\
7\end{array}$ & 1 & 1 & 1 & 1 & 1 & 1 & 1 & 7 & 1.00 & 1.00 \\
\hline & $\begin{array}{c}\text { Item } \\
8\end{array}$ & 1 & 0 & 1 & 1 & 1 & 1 & 1 & 6 & 0.86 & 0.71 \\
\hline & $\begin{array}{c}\text { Item } \\
9\end{array}$ & 1 & 1 & 1 & 1 & 1 & 0 & 1 & 6 & 0.86 & 0.71 \\
\hline & $\begin{array}{c}\text { Item } \\
10\end{array}$ & 0 & 1 & 1 & 1 & 1 & 1 & 1 & 6 & 0.86 & 0.71 \\
\hline & $\begin{array}{c}\text { Item } \\
11\end{array}$ & 1 & 1 & 1 & 1 & 1 & 1 & 1 & 7 & 1.00 & 1.00 \\
\hline & $\begin{array}{c}\text { Item } \\
12\end{array}$ & 1 & 0 & 1 & 1 & 1 & 1 & 1 & 6 & 0.86 & 0.71 \\
\hline & $\begin{array}{c}\text { Item } \\
13\end{array}$ & 1 & 1 & 1 & 1 & 1 & 0 & 1 & 6 & 0.86 & 0.71 \\
\hline
\end{tabular}

\section{RESULTS AND DISCUSSION}

\section{A. Results}

TABLE I. RESULTS OF EXPERT JUDGMENT

TABLE II. VALIDITY SCORE

\begin{tabular}{cccc}
\hline No & Item & Validity score & Remark \\
\hline $\mathbf{1}$ & Item $\mathbf{1}$ & 0.71 & Valid \\
$\mathbf{2}$ & Item $\mathbf{2}$ & 0.71 & Valid \\
$\mathbf{3}$ & Item $\mathbf{3}$ & 1.00 & Valid \\
$\mathbf{4}$ & Item $\mathbf{4}$ & 0.71 & Valid \\
$\mathbf{5}$ & Item $\mathbf{5}$ & 0.71 & Valid \\
$\mathbf{6}$ & Item $\mathbf{6}$ & 0.71 & Valid \\
$\mathbf{7}$ & Item $\mathbf{7}$ & 1.00 & Valid \\
$\mathbf{8}$ & Item $\mathbf{8}$ & 0.71 & Valid \\
$\mathbf{9}$ & Item $\mathbf{9}$ & 0.71 & Valid \\
$\mathbf{1 0}$ & Item $\mathbf{1 0}$ & 0.71 & Valid \\
$\mathbf{1 1}$ & Item $\mathbf{1 1}$ & 1.00 & Valid \\
$\mathbf{1 2}$ & Item $\mathbf{1 2}$ & 0.71 & Valid \\
$\mathbf{1 3}$ & Item $\mathbf{1 3}$ & 0.71 & Valid \\
\hline
\end{tabular}

It can be inferred from the results presented in Table 1 and Table 2 that the indicators of enjoyment in the instrument were still valid. The reasons why it was valid would be explained in the next chapter namely Discussion chapter.

\section{B. Discussion}

The objective of the study was to estimate the value of content validity of the enjoyment istrument in physical education process. It has been discussed before that content validity is one of validity tests in instrument development process. In content validity test, a test item was categorized valid if it is properly developed based on the indicators, content, and learning objectives by the experts of the field [7]. Some of the techniques to measure the content validiry are (1) percentage of the indicators and objects; (2) matching index of the indicators and objectives; (3) content validity ratio from Lawshe; and (4) V index from Aiken [7,8,10,11]. Meanwhile, the analysis technique used in this study is Lawshe's content validity ratio.

The results show that the content validity using Lawshe's technique was ranging from 0.71 to 1.00 . the minimum number of the ratio was still higher than 0.50 indicating that even though there was an expert stating that it was not valid, it was actually valid over all. This result is in line with a theory proving that content validity ratio is influenced by the number of experts involved and stating how valid it is [8]. Furthermore, the ratio index ranging $-1 \leq \mathrm{CVR} \leq+1$ with the $\mathrm{Mp}$ criteria $<1 / 2$ $\mathrm{M} \mathrm{CVR}<0 ; \mathrm{Mp}=1 / 2 \mathrm{M} \mathrm{CVR}=0 ; \mathrm{Mp}>1 / 2 \mathrm{M}$ CVR $>0[8,10-$ 12] indicating that revision is needed based on the feedback given by the experts acting out as the respondents in this study giving their judgment on the content validity of the instrument [1]. This is in agreement with a study saying that content validity should find out how far the items cover the entire area of the objects measured [11].

The results in this study also support previous studies' results conducting a qualitative test followed by empirical validity test [13]. Previous studies show consistency with the results of this study as well [1,14-18]. However, some studies measured the content validity using a percentage technique $[19,20]$. The analysis aims to measure the agreement of the experts using percentage ranging from $0 \%$ to $100 \%$.

\section{CONCLUSION}

The results of initial validity test showed that the enjoyment instrument of physical education used in a junior high school in Indonesia was proven valid. Therefore, the instrument is able to give feedback on students' enjoyment in physical education. This also means that the more enjoyment students have, the more effective the teaching and learning process in physical education gets.

\section{REFERENCES}

[1] Y. Yudiana, Y. Hidayat, and B. SS. Hambali, "Content Validity Estimation of Assessment Instrument Based on Volleyball Information System of Volleyball Learning: Field Research,” IOP Publ IOP Conf Ser Mater Sci Eng, vol. 180, no. (1), pp. 1-7. 
[2] J.R. Morrow, A.W. Jackson, J.G. Disch, and D.P. Mood, Measurement and evaluation in human performance. (3rd Edn). Canada: Human Kinetics, 2005

[3] A.C. Lacy, Measurment \& Evaluation in Physical Education and Exercise Science. San Francisco: Pearson Education, Inc, 2011.

[4] M.Z. Husain, A. Hasan, N.B.A. Wahab, and J. Jantan, "Determining Teaching Effectiveness for Physical Education Teacher," Procedia Social and Behavioral Sciences, vol. 172, pp. 733-740, 2015.

[5] Undang-Undang Sistem Keolahragaan Nasional nomor 3 Tahun 2005.

[6] B. Johnson and L. Christensen, Educational research: Quantitative, qualitative, and mixed approaches. (4th. Eds). Los Angeles: Sage Publication, Inc, 2012.

[7] N.K. Denzin, and Y.S. Lincoln, Handbook of Qualitative Research Edisi Bahasa Indonesia. Yogyakarta: Pustaka Belajar, 2009.

[8] B. Susetyo, Menyusun Tes Hasil Belajar. Bandung. CV. Cakra, 2011.

[9] D. Kendzierski, and K.J. DeCarlo, "Physical Activity Enjoyment Scale: Two validation studies," Journal of Sport \& Exercise Psychology, vol 13, no. (1), pp. 50-64, 1991

[10] J.R. Gregory, Tes Psikologi, Sejarah, Prinsip, dan Aplikasi. Jakarta: Edisi Keenam. Erlangga, 2011

[11] S. Azwar, Penyusunan skala psikologis. Yogyakarta: Pustaka Pelajar, 2012

[12] D.S. Naga, Teori Sekor Pada Pengukuran Mental. Jakarta. Nagarani Citrayasa, 2012.

[13] Hidayat and Mudjihartono, Reliabilitas and factorial validity Of Basic Skills Learning Achievement Among. Proceding International Conference On Sport and Physical Education. FPOK UPI, 2014.
[14] T. Shopia, L. Grant, A. Jhon, Spertus, K. Irfan, A. Rob, M. Garen, and J. Robert, "Development and Content Validity Testing of a PatientReported Treatment Acceptance Measure for Use in Patients Receiving Treatment via Subcutaneous Injection," Journal Value In Health, no. (18), pp. 1000-1007, 2015.

[15] J. Golnaz, H. Hossein, and C. Azizeh, "Content Validity Analysis of the Master Program in TEFL," Procedia Social and Behavioral Sciences, no. (136), pp. 293-297, 2014.

[16] A. Maarten, D. Carin, S. Martijn, L.U. Nico, J.M. Paul, P. Beth, and D Diane, "Content validity of the Dutch version of the Neck Bournemouth Questionnaire,” Journal Manual Therapy, no. (18), pp. 386-389, 2013.

[17] S.E. Jensen, K. Kaiser, L. Lacson, J. Schink, and D. Cella, "Content validity of the NCCN-FACT Ovarian Symptom Index-18 (NFOSI-18)," Journal Gynecologic Oncology, no. (136), pp. 317-32, 2015.

[18] I. Maria, M. Teresa, S. Allison, F. Carmen, M. Loreto, and G. Esther, "Content validity of the Spanish version of the Practice Environment Scale of the Nursing Work Index," Journal Applied Nursing Research, no. (26), pp. e5-e9, 2013.

[19] L.P. Donald, B.B. Laurie, J.G. Chad, K.L. Nancy, L.M. Mona, M Elizabeth R. Lena, "Content Validity-Establishing and Reporting the Evidence in Newly Developed Patient Reported Outcomes (PRO) Instruments for Medical Product Evaluation: ISPOR PRO Good Research Practices Task Force Report: Part 1-Eliciting Concepts for a New PRO Instrument,” Journal Value In Health, vol. (14), pp. 967-977, 2011.

[20] M. Ohiro, Pengembangan Rubrik Penilaian Proposal Penelitian Mahasiswa Pada Program Studi Tardis Biologi Jurusan Tarbiyah Stain Kerinci. Tesis UNP, 2013. Tidak diterbitkan. 